\title{
Flat oyster cultivation in Galicia
}

\author{
A. Figueras \\ Instituto de Investigaciones Pesqueras; Vigo, Spain
}

\begin{abstract}
EXTRAIT: La culture de l'huître plate en Galice. Malgré de nombreuses tentatives scientifiques ou industrielles entreprises en Espagne, et malgré les conditions favorables offertes par les baies de la côte de Galice, on n'a pas encore réussi à y implanter une véritable ostréiculture industrielle, contrairement au succès de la mytiliculture. Les gisements naturels de l'huître plate (Ostrea edulis L.) furent épuisés il y a plusieurs années, sauf quelques vestiges sur la côte de Galice, et l'ostréiculture galicienne est maintenant limitée à la conservation, de mars à novembre, d'huîtres importées surtout de Bretagne, âgées de 2 à 3 ans, que l'on fixe à des cordes suspendues verticalement à des pontons afin d'assurer leur croissance et leur engraissement. De la sorte, les huîtres échappent en général à l'élévation de la température, qui provoquerait leur ponte, et par ailleurs la fixation du naissain est défectueuse en raison de l'absence de collecteurs naturels ou artificiels. Des expériences d'ostréiculture sont actuellement poursuivies soit à l'aide des méthodes traditionnelles utilisant des collecteurs de tuiles, soit avec du naissain artificiel. Dans les conditions de culture traditionnelles, la mortalité des huîtres adultes est élevée et le rendement parfois médiocre, en raison de la salinité réduite durant l'hiver, du manque d'oxygène en été, et du substrat défectueux; les huitres qui survivent présentent une croissance et un engraissement extrêmement satisfaisants. Des expériences sont en cours avec des naissains élevés soit en bassins clos, soit sur des espaces naturels semi-confinés, et sur l'alimentation des huitres à l'aide de cultures de phytoplancton ou de produits amylacés.
\end{abstract}

\section{INTRODUCTION}

Several industrial and scientific attempts have been carried out in Spain to develop the oyster cultivation. None of the attempts were successful (ANDrEu 1962, 1967, 1968, Madariaga de la Campa 1969).

We think that factors other than natural conditions have been responsible for the failure. Perhaps the oyster has never been a popular food in Spain: in the Louvre Museum can be seen only one picture by the Spanish painter NúN̄EZ DE VILLAvicencio (1644-1700) "los comedores de mejillón" ("Mussel Eaters"), but there are many paintings of the French school in which oysters appear.

\section{METHODS AND RESULTS}

At present, Spanish industrial firms and scientists carry out a number of projects aimed at a successful cultivation of the oyster Ostrea edulis, especially in Galicia (Northwest Spain). About 10 million oysters are maintained on floating rafts. 
The natural beds of flat oysters have been exhausted for several years; only some residual beds still exist in Galician bays. The Galician oyster cultivation is now based on imports (principally from Brittany) of middle sized oysters which are cultivated from March to November. They are attached with cement to ropes, for growth and fattening. Some of them are maintained in synthetic trays ("netlon"), but this technique is not common. Very few oysters are maintained on the sea bottom in natural parks

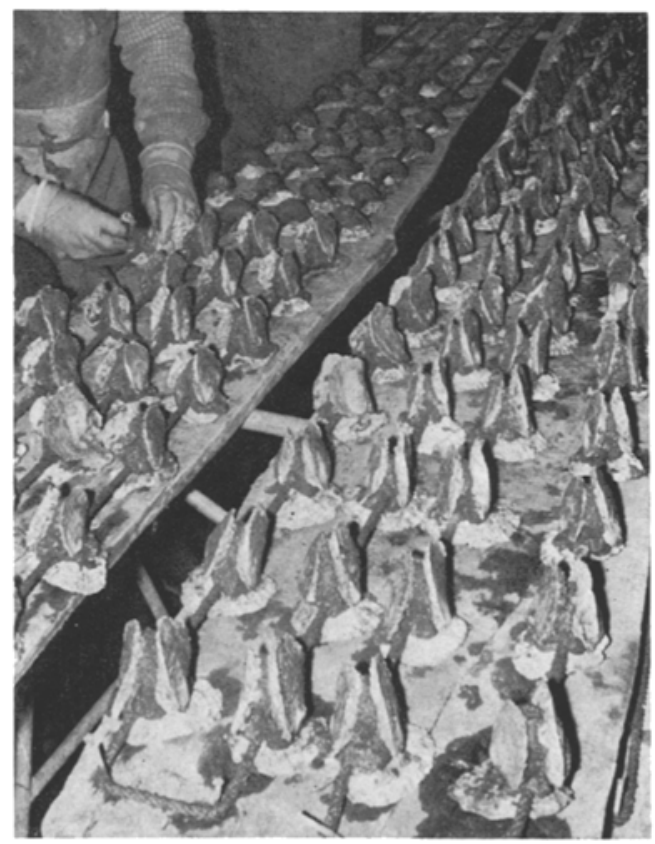

Fig. 1: Fastening of oysters (Ostrea edulis) with cement on the culture ropes

("concesiones"). Neither cultch (shells and gravel) nor other collectors for spat are employed, except in the cases cited above. Cultch becomes more and more scarce; the shells are used for making flour and the great number of mussel rafts produce large amounts of organic detritus.

In the cultivation experiments carried out in the Villajuan oyster culture park, we found it more profitable to spend more money on tiles and shells as spat collectors than on parent oysters. Figures 1-4 illustrate the various aspects of oyster cultivation mentioned.

Oyster cultivation on ropes (cement attachment) has been dealt with by ANDREU $(1967,1968)$. This cultivation technique can be recommended for growing and fattening, but as the rope is suspended in a vertical position (the uppermost oysters are at $50 \mathrm{~cm}$ from the water surface) the majority of the oysters do not respond to the temperature increases which stimulate spawning. The relatively high costs are compensated for by the high prices of oysters on the interior market. 
The oysters maintained on ropes are handled three times. First, they are attached to the ropes; during eight hours per day, twelve women workers can handle about $800-1,000 \mathrm{~kg}$ of oysters (20-30 units per $\mathrm{kg}$, depending on size). Shipments can be of 8-10 tons once or twice a year. Second, the oysters are cleaned from seaweeds and
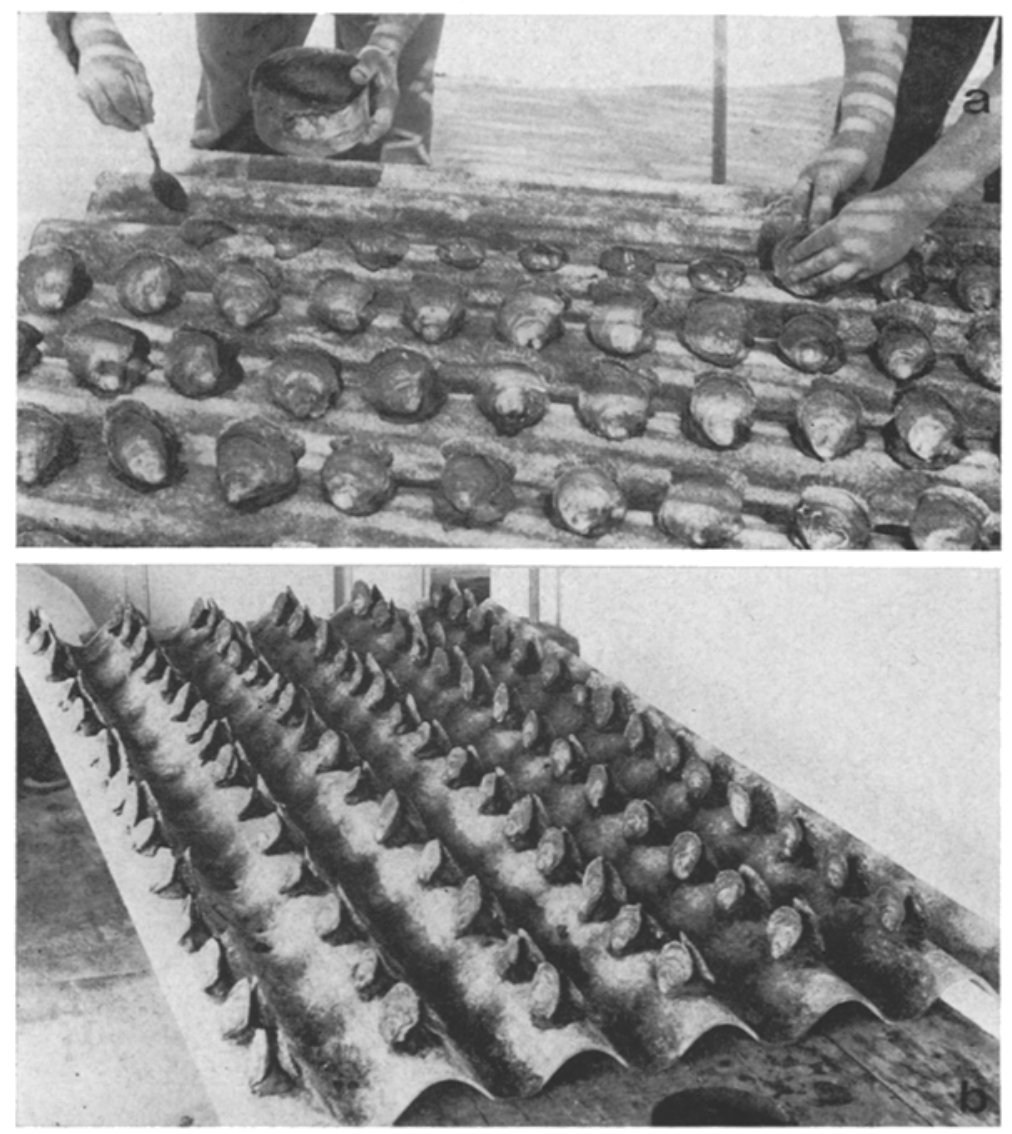

Fig. 2: Oysters (Ostrea edulis) attached with cement to fibrocement plates (uralite). The plates are later placed on the sea bottom in the culture area

other organisms on the ropes during August or early September. Third, when the season starts in November, oysters are detached from the ropes and cleaned once again.

In 1951 the Instituto of Investigaciones Pesqueras (Fisheries Research Institute) started (at the Laboratory in Vigo) several attempts toward oyster cultivation in Galicia. In 1954 the first cultivation attempts began in the Ria of Vigo (ANDREU \& ARTe 1955). In regard to rates of settlement and growth very good results were obtained but social problems stalled experiments.

In 1965, a second attempt was initiated in Ria of Arosa; here we encountered the following obstacles: there was no parent oyster stock and we had not enough money 
available to establish one; it was necessary to modify the bottom quality and to correct previous information on environmental factors; fresh water inflow during
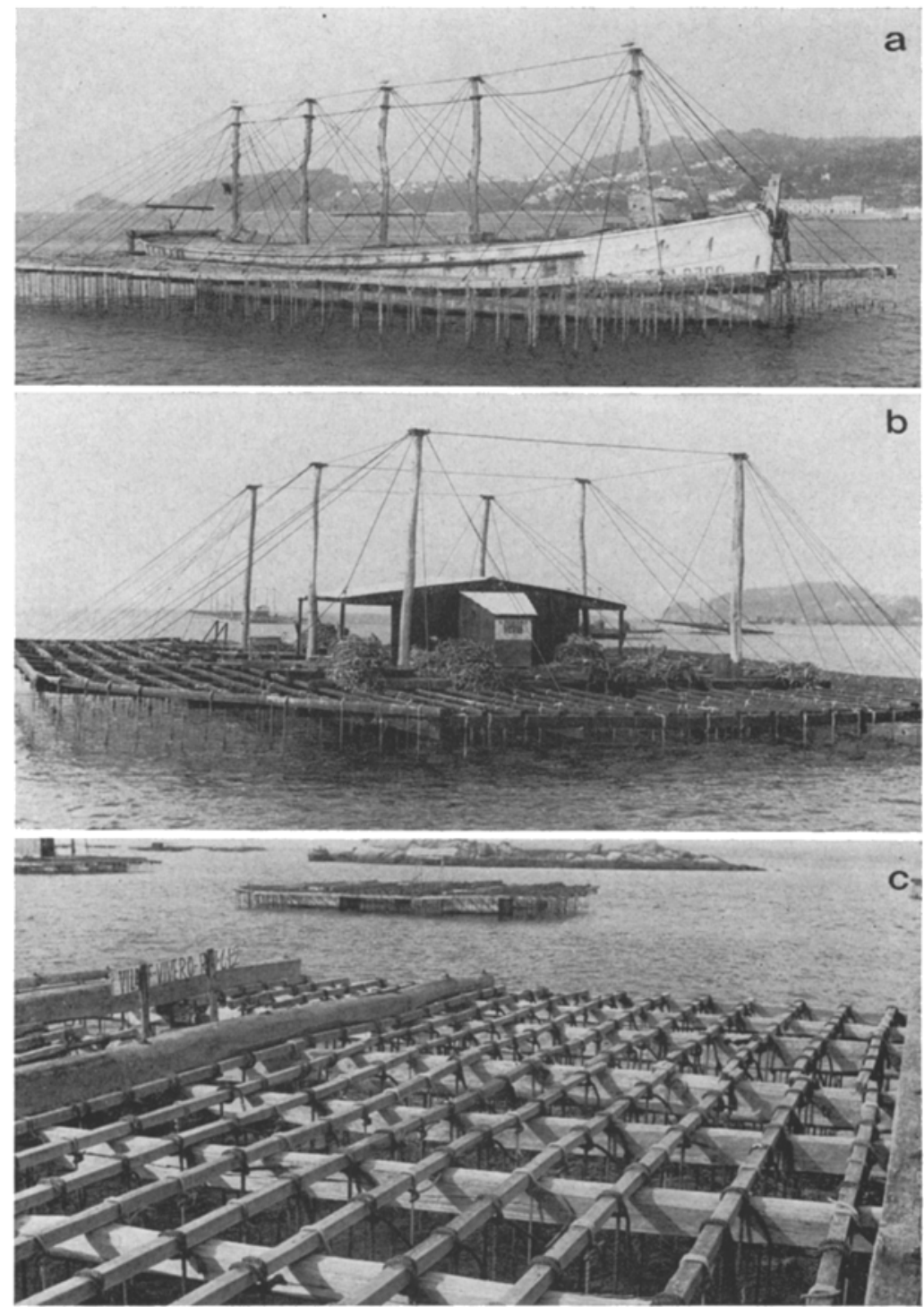

Fig. 3: Different types of mussel rafts; $a$ old boat surrounded by rafts; $b$ raft with small house (Vigo Bay); $c$ similar raft without house (Arosa Bay)

winter and early spring resulted in high rates of mortality (ANDREU \& FIGUERAs 1967, Figueras 1969, Figueras \& ANDREu 1968); finally, the bottom turned out to be too muddy to maintain the oysters directly on the ground. We first planned to overcome 
all these obstructions and tried to harden the bottom by means of shells, gravel, etc., to maintain oysters on a net of "netlon", or on flat bags of the same material, or in wooden boxes (similar to the French "caisses ostréophiles"). Finally, we fastened oysters with cement on fibrocement (uralite) plates which are used for house roofs (Fig. 2). In all cases, except in the last one, we found fast and convenient removal
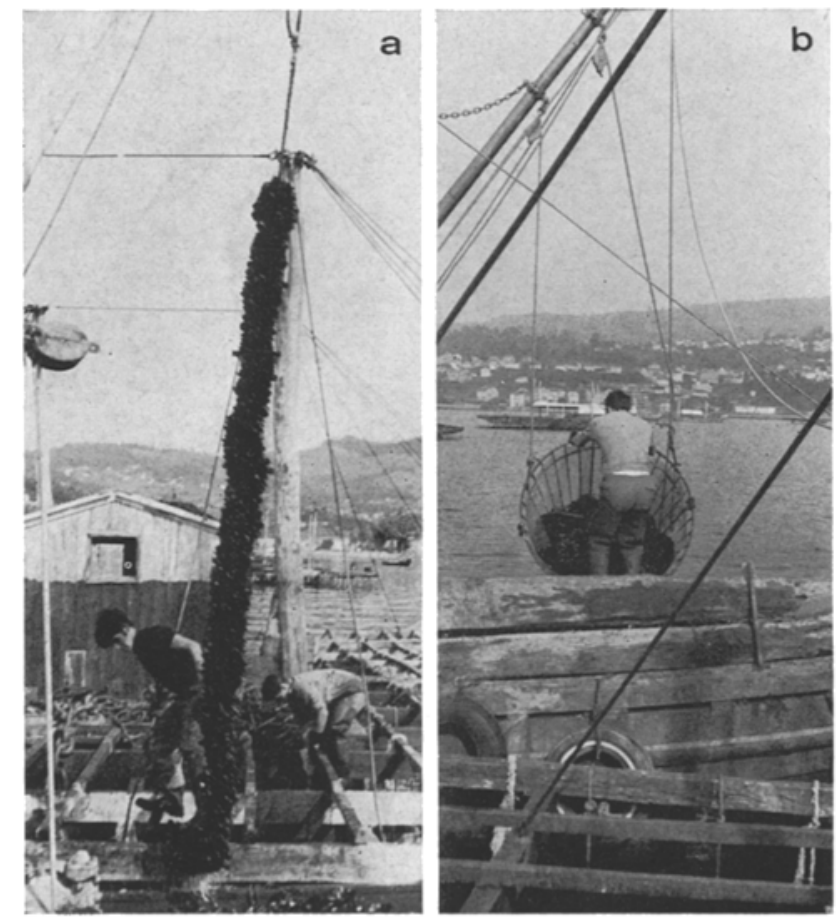

Fig. $4: a$ rope with mussels attached; $b$ special basket for collection of mussel ropes

(required during periods of intensive fresh water inflow) difficult. On the fibrocement plates, the oysters are fixed and protected from the pulling forces of extensive water movement during low tides and rough weather.

In order to obtain spat we have tried the conventional spat collectors of limed tiles (a technique used in Brittany). The results were very satisfactory regarding our small quantities of parent oysters, the oyster larvae's competition for space, the small number of tiles $(3,000-5,000)$, and our ignorance with respect to the most suitable localities.

We have also experimented with laboratory-raised spat both in closed tanks and in natural, semi-confined sea areas. Problems of maintainance and fattening of oysters with cultivated phytoplankton food and amylaceous products are now being investigated. 


\section{SUMMARY}

1. Spanish industrial frms and scientific institutions are interested in cultivating the oyster, Ostrea edulis L., for commercial and scientific purposes. Even though bays in Galicia (Northwest Spain) appear to be well suited for oyster cultivation, success has been rather limited thus far.

2. The local natural beds of Ostrea edulis are largely exhausted for several years. The Galician oyster cultivation is, therefore, at present limited to the import of middle sized oysters (mainly from Brittany) and their fattening during the favourable season, i.e. March to November, in suitable natural habitats.

3. Sufficient rates of reproduction of the fattened oysters are difficult to attain because (a) the oysters are attached to vertically arranged ropes and hence not stimulated to spawn simultaneously (large vertical gradient at critical temperature which stimulates spawning), (b) settling oyster larvae are not sufficiently attracted due to the absence of suitable natural and artificial substrates.

4. Experiments are presently being carried out employing traditional larvae collectors (tiles) and laboratory-raised oyster spat fed on phytoplankton cultures and amylaceous products.

5. Low salinities in winter, lack of oxygen in summer and adverse qualities of the natural substratum increase the mortality. Under present circumstances, fattening of middle-sized oysters appears to be still the most satisfactory method with regard to commercial view points.

\section{LITERATURE CITED}

ANDREu, B., 1962. Ordenación de la explotación marisquera. Aspectos cientificos y técnicos del cultivo del mejillón e industrialización de la ostra en Galicia. In: Segundo Consejo Económico Sindical Provincial. Vigo, Pontevedra.

- 1967. Explotación marisquera. Ciencias 32 (4).

- 1968. Pesquería y cultivo de mejillones y ostras en España. Publnes téc. Junta Estud. Pesca 7.

- \& ARte, P., 1955. Experiencias previas sobre la fijación de larvas y crecimiento invernal de la ostra joven (Ostrea edulis) en las rías gallegas (NW de España). Publnes Inst. Biol. apl. Barcelona 19, 115-129.

- \& Figueras, A., 1967. Parque experimental de ostricultura de Villajuán. Estudio preliminar de las condiciones ambientales, crecimiento y adaptación de la ostra plana y del ostión. Publnes téc. Junta Estud. Pesca 6.

Figueras, A., 1969. Parque experimental de ostricultura de Villajuán. III. Experiencias realizadas en el periodo de octubre de 1967 a noviembre de 1968. Publnes téc. Junta Estud. Pesca 8.

- \& Andreu, B., 1968. Parque experimental de ostricultura de Villajuán. Estudio de los factores ambientales, crecimiento y mortalidad de la ostra plana y del ostión; II: período 1966-67. Publnes téc. Junta Estud. Pesca 7.

Madariaga de la Campa, B., 1969. La ostricultura en España. In: Consejo General de Veterinarios de España. Ed. S. Francisco de Asís, Madrid.

Author's address: Dr. A. Fugueras

Instituto de Investigaciones Pesqueras

Orillamar 47,

Vigo, Spain 